\title{
Study on Province-wide Evaluation Index System of Energy-saving and Emission-reduction in China
}

\author{
Shuang Wang \\ Economics and Management College, Dalian University, Dalian, 116600, China \\ wshuang1021@sina.com
}

\begin{abstract}
Keywords: Energy-saving and emission-reduction; Index system; Evaluation
Abstract. At present, research on energy-saving and emissions reduction is still mainly theoretical construction and not much quantitative research on evaluation, particularly study of the empirical analysis on the provinces and the national is rarely. In order to arrange energy-saving and emissionsreduction better, achieve the strategic target for energy-saving and emission-reduction, improve production environments, make comprehensive use of resources and develop circular economy, the establishment of a comprehensive and perfect evaluation system of province-wide energy-saving and emission-reduction is of great significance both to the region and the country. This thesis attempts to build up a set of 19 indicators specific indicators system, can basically achieve targets for the quantitative evaluation of province-wide energy-saving and emission-reduction.
\end{abstract}

\section{Definition of Energy-saving and Emission-reduction}

"Energy Conservation Law of the People's Republic of China" puts forward specific definition for energy-saving and emission-reduction respectively: Energy-saving is to point to strengthen energy management and take measures of feasible technically, rational economically and acceptable environmentally and socially, reduce consumption, the loss and pollutant discharge, cut waste and effective and reasonable use of energy from all aspects of energy production to consumption.

Emission-reduction refers to reduce the emissions of gas pollution, greenhouse gas, solid waste, heavy metals (such as lead, cadmium, etc.), and radioactive substances, etc. The objects of reduction mainly include $\mathrm{SO}_{2}$, suspended particles, (such as dust, smoke, etc.), nitrogen oxides, heavy metals, greenhouse gases and so on.

Sustainable development means that "it not only meets the demand of contemporary, but also has the ability for the future generations to meet their demand of development". Energy-saving and emission-reduction targets based on the least amount of resource consumption to obtain the biggest economic and social benefits, safeguard social and economic sustainable development ${ }^{[1]}$, so it is necessary to establish a set of evaluation index system of energy-saving and emission-reduction, which is to monitor the result of energy-saving and emission-reduction regularly and quantitatively in different provinces and regions.

\section{The Construction Principle of Energy-saving and Emission-reduction Index System}

\section{Comprehensive and scientific of the system}

Comprehensive means that we should be all-round coverage of energy-saving and emission-reduction work, widely consider various factors that may affect the energy-saving and emission-reduction, systematically collected selection. The choice of evaluation index can't please attention to all side of matters, which should be in accordance with the scientific method, filter strong representative what can reflect the essence content of energy-saving and emission-reduction work and guarantee that evaluation indicators are scientific, reasonable and instructional.

\section{Comparability}

The index system should consider that the requirements of the different periods of dynamic contrast and comparison in different parts of the space to ensure that the system play a proper role and 
make the index system has good tolerance and comparable to facilitate the analysis of actual application and meet the needs of different subjects.

\section{Maneuverability}

In order to make energy-saving and emission-reduction index system can be effectively applied in practical analysis, solve practical problems, the concept of selecting indicators and the content must be clear and has observables, and have the corresponding data support, rather than take a one side pursuit of perfect theoretical level ${ }^{[2]}$.

\section{The Construction of Evaluation Index System of Energy-saving and Emission-reduction}

Based on the research and analysis of interrelated indicators of energy- saving and Emission-reduction at home and abroad, combined with the meaning of our country's current energy-saving and Emission-reduction, and followed the construction principle of index, through analyzing and comparing repeatedly and based on the theory and feasibility of balanced coordination, this thesis designs a set of composed of 19 specific indicators evaluation index system, which has a simple structure, high maneuverability, the crosswise comparison can realize various provinces and cities and the regions, a certain research value, as shown in table 1.

Table 1 The Evaluation Index System of Energy-saving and Emission-reduction

\begin{tabular}{|c|c|c|c|c|}
\hline $\begin{array}{c}\text { First } \\
\text { grade index }\end{array}$ & $\begin{array}{l}\text { Secondary } \\
\text { grade index }\end{array}$ & $\begin{array}{l}\text { Third } \\
\text { grade index }\end{array}$ & Fourth grade index & Unit \\
\hline \multirow{19}{*}{$\begin{array}{l}\text { The } \\
\text { evaluation } \\
\text { index } \\
\text { system of } \\
\text { energy-saving } \\
\text { and } \\
\text { emissions- } \\
\text { reduction }\end{array}$} & \multirow{7}{*}{ Energy-saving } & \multirow{4}{*}{$\begin{array}{l}\text { Comprehensive } \\
\text { energy consumption }\end{array}$} & Energy consumption Per Unit GDP & $\begin{array}{l}\text { ton/ } \\
\text { ten-thousand-yuan }\end{array}$ \\
\hline & & & $\begin{array}{l}\text { Electricity consumption per unit } \\
\text { GDP }\end{array}$ & $\begin{array}{l}\mathrm{Kw} / \\
\text { ten-thousand-yuan }\end{array}$ \\
\hline & & & Water consumption per Unit GDP & $\begin{array}{l}\text { ton/ } \\
\text { ten-thousand-yuan }\end{array}$ \\
\hline & & & Oil consumption per Unit GDP & $\begin{array}{l}\text { ton/ } \\
\text { ten-thousand-yuan }\end{array}$ \\
\hline & & \multirow{3}{*}{$\begin{array}{l}\text { Use of renewable } \\
\text { energy }\end{array}$} & $\begin{array}{l}\text { Consumption ratio of renewable } \\
\text { energy }\end{array}$ & $\%$ \\
\hline & & & Utilization of Crop straw resources & $\%$ \\
\hline & & & $\begin{array}{l}\text { The penetration rate of Clean } \\
\text { energy in Countryside }\end{array}$ & $\%$ \\
\hline & \multirow{12}{*}{$\begin{array}{l}\text { Emission- } \\
\text { reduction }\end{array}$} & \multirow{5}{*}{ Pollutant discharge } & $\begin{array}{l}\text { Total discharge Amount of Sulfur } \\
\text { Dioxide }\end{array}$ & ton \\
\hline & & & Total discharge amount of COD & ton \\
\hline & & & Wastewater effluent & ten thousands tons \\
\hline & & & Emission of waste gas & billion $\mathrm{m}^{3}$ \\
\hline & & & Solid waste production & ten thousands tons \\
\hline & & \multirow{7}{*}{$\begin{array}{l}\text { Pollutant disposal } \\
\text { and utilization }\end{array}$} & The removal rate industrial $\mathrm{SO}_{2}$ & $\%$ \\
\hline & & & The removal rate industrial COD & $\%$ \\
\hline & & & The removal rate of industrial dust & $\%$ \\
\hline & & & $\begin{array}{l}\text { The attainment rate of industrial } \\
\text { wastewater discharge }\end{array}$ & $\%$ \\
\hline & & & $\begin{array}{l}\text { The rate of industrial reusing } \\
\text { process water }\end{array}$ & $\%$ \\
\hline & & & $\begin{array}{l}\text { The comprehensive utilization rate } \\
\text { of industrial solid wastes }\end{array}$ & $\%$ \\
\hline & & & $\begin{array}{l}\text { Innocent treatment rate of urban } \\
\text { garbage }\end{array}$ & $\%$ \\
\hline
\end{tabular}

The evaluation index system divided into two secondary indexes: energy-saving and emission-reduction from the meaning of energy -saving and emission-reduction. As for the energy 
saving system, we proposed to reflect the overall level of the energy-saving and the absolute level of energy consumption through the comprehensive energy consumption dimension and to reflect the dimension of advocating the development of new renewable energy use level through renewable energy use. This renewable energy generally includes hydropower, wind energy, solar energy, geothermal energy, biomass energy, etc. Compared with the fossil energy, renewable energy had a variety of advantages, such as the sustainable exploitation and utilization and low environmental pollution but due to the requirements of the general technical level is high capacity, productivity in short time is limited, therefore, so far, the demand for energy is mainly depend on fossil energy, the development and use level of renewable energy is still low. However, renewable energy is of primary importance of energy-saving all over the world in the future. For emission-reduction system, we proposed to reflect the total scale of wastewater, waste gas and solid waste during the whole process of the economic cycle through the pollutant discharge dimension, to reflect that meet the national standards of emissions of major pollutants process level through pollutant treatment and utilization. The explanations of specific indexes are as followed:

\section{The Dimension of Comprehensive Energy Consumption}

The thesis selects Energy Consumption per Unit GDP, Electricity consumption per unit GDP, Water Consumption per Unit GDP, and oil consumption per Unit GDP for specific indicators, for coal accounted for $68.5 \%$, oil $17.7 \%$, water $7.1 \%$, natural gas $4.7 \%$, nuclear power $0.8 \%$, other $1.2 \%$ in Chinese energy consumption structure. The energy consumption per unit GDP is shown in Fig.1. In 2013, energy consumption per unit GDP in China was 2.5 times of the average level in the whole world, 3.3 times that of the United States, 7 times that of Japan, at the same time, higher than that of developing countries such as Brazil and Mexico. On the basis of the total energy consumption, if Chinese energy consumption per unit GDP reached the world average, China's GDP scale could reach 87 trillion Yuan, the energy consumption per unit GDP reached the United States average, could reached 109 trillion Yuan GDP; reached Japan's average, the scale of GDP for 175 trillion Yuan ${ }^{[3]}$.

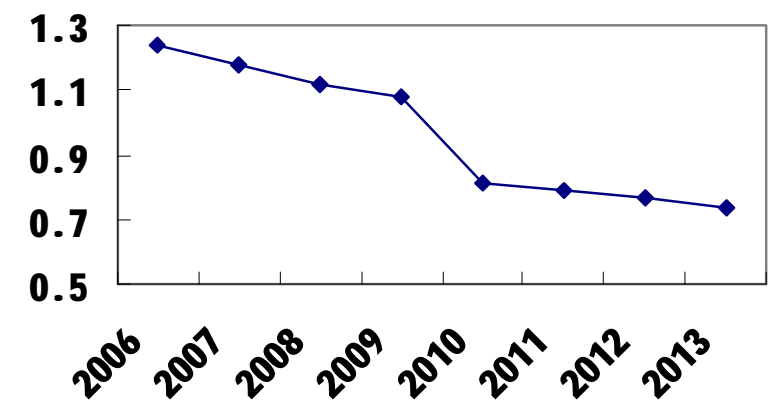

Fig.1 The time sequence diagram on energy consumption unit GDP in our country

\section{The Usage of Renewable Energy}

With the rapid development of China's economy in recent years, energy consumption has mainly relied on a large amount of consumption of coal, but in the process of using coal produced a large number of sulfide, which caused more serious air pollution in our country during the process of industrialization compared with the developed countries, and brought the adverse effect for the social development and people's life. Therefore, adjusting the energy structure is inevitable and also the scientific laws of saving energy consumption, steadying development of hydropower, testing nuclear power scale, speeding up the development of natural gas, developing wind, solar, biomass energy, geothermal energy and other renewable energy sources to adapt local conditions. And China is an agricultural country which includes the total population of nearly 800 million people who are concentrated in the rural areas at present. The improvement of rural energy-using condition is very important to improve the whole national renewable energy use, which combined with the actual 
situation of our country rural area and used the crops straw resource utilization and clean energy rate for research index.

\section{The Pollutants Emissions}

Pollutant emissions come mainly from industrial production process in our country, so industries and enterprises are mainly total amount of the statistical pollutant major object. For example, oil processing and coking and nuclear fuel processing industry, chemical raw materials and chemical products manufacturing industry, nonmetal mineral products, ferrous metal smelting and rolling processing industry and other industries are the main body in pollutants emissions. The thesis constitutes index contents according to the three forms of pollutants: waste water, waste gas and solid waste. And it also selected the main pollutant emissions of $\mathrm{SO}_{2}$ and COD as separate statistical index, reflected pollutants situation in our country at present by combination of synthesis and specific emissions. These index values can be directly observed and provided convenience for the following quantitative evaluation.

\section{Pollutant Disposal and Utilization}

Appropriate treatment of pollutants could greatly reduce the pollution damage to the environment and processing recycling could create certain social economic benefits. The major developed countries have achieved very good results on the pollutant emissions treatment and reuse currently. China's emissions should focus on, of course, how to achieve effective processing and utilization of pollutants, which put forward to the specific requirements in the national environmental protection of "twelfth five-year" plan. There were a large number of experts and scholars engaged in the research under the supporting benefit of national policy and also got some achievements in various industries. For example, innocent treatment rate of urban garbage in China reached $84.8 \%$ in 2012, and most of the regions reached more than $80 \%$. But the road of pollutants treatment related to the development of industrial production in the future is still long, how to weigh the relationship of pollutants emission and economic development still is the common problem in the world.

\section{Conclusion}

Only when governments supervise can the work of energy-saving and emission-reduction require to success. And the most effective strategy of supervision is quantitative. Establishing a set of evaluation index system is the most convenient and quick method in statistical methodology, but the difficulty is that how to establish a set of system with extensive comparative significance, monitoring energy-saving and emission-reduction work in the progress of provinces and cities, which also the problems discussed in this thesis. The author considers that constructing evaluation index system of province-wide energy-saving and emission-reduction should be paid attention to the following two points: one is that the specific target must select the regular basis accounting index in different provinces; the other is that the index value should be relatively easy to obtain.

\section{Acknowledgement}

This research was supported by Social Science Foundation of Liaoning Province (L13DTJ005).

\section{References:}

[1] Chen Qingxia, The Evaluation Research on Energy-saving and Emission-reduction Efficiency in Yangtze River Delta [D]. Shanghai Jiao Tong University, 2010, (3)

[2] Wang Guiwei, The Design Principle of the Index System on Energy-saving and Emissions-reduction in Dalian [J]. Dalian Daily, 2014,(11)

[3] Shen Pin, Deng Mingran,etc. Research on Evaluation System of Energy-saving and Emission-reduction in Resources and the Environment Oriented Enterprise [J]. Journal of 
Wuhan University of Technology,2010,32(4)

[4] Li Xia, Comprehensive Evaluation a Index System Empirical Research on Energy Conservation and Emissions Reduction in Provincial Area of China [J]. Economic Review, 2013(4) 